\title{
Lost in authoritarian development
}

Have global climate deals and the aid community sacrificed the Vietnamese highland population?

Bruun, Ole

Published in:

Development Policy Review

DOI:

10.1111/dpr.12432

Publication date:

2020

\section{Document Version}

Peer reviewed version

Citation for published version (APA):

Bruun, O. (2020). Lost in authoritarian development: Have global climate deals and the aid community sacrificed the Vietnamese highland population? Development Policy Review, 38(4), 501-520.

https://doi.org/10.1111/dpr.12432

\section{General rights}

Copyright and moral rights for the publications made accessible in the public portal are retained by the authors and/or other copyright owners and it is a condition of accessing publications that users recognise and abide by the legal requirements associated with these rights.

- Users may download and print one copy of any publication from the public portal for the purpose of private study or research.

- You may not further distribute the material or use it for any profit-making activity or commercial gain.

- You may freely distribute the URL identifying the publication in the public portal.

\section{Take down policy}

If you believe that this document breaches copyright please contact rucforsk@kb.dk providing details, and we will remove access to the work immediately and investigate your claim. 


\section{Lost in authoritarian development: Have global climate deals and the aid community sacrificed the Vietnamese highland population?}

Ole Bruun ${ }^{1}$

\section{Structured abstract}

Motivation

Global climate agreements and associated funding mechanisms tend to ignore the knowledge and experience accumulated in conventional aid interventions over several decades. The consequences are particularly pronounced in authoritarian regimes, where marginal population groups may be subjected to technocratic development plans in the name of global climate goals and social safeguards are difficult to monitor.

Purpose

The article examines the implications of climate-related interventions for ethnic minority communities in the highlands of Vietnam, as they are caught in the conflicting development logics between the international donor community, vowing to defend their interests, and the Vietnamese government administration.

\section{Approach}

The study builds on a comprehensive household survey on REDD+ activities and livelihoods in two districts (three communes) in upland Lao Cai province, northern Vietnam. The survey was supplemented with in-depth interviews with villagers, extensive talks with governments (People's Committees) at provincial, district and commune level, and various observations and interviews across the province.

\section{Findings}

The study finds that embeddedness is of key importance. However well-intended climate-related interventions may be, they cannot alter crucial conditions of social organisation and governance. In the highlands of Vietnam, climate-related funding tends to be aligned with a long series of government programmes for highland transformation and the assimilation of ethnic minorities

\footnotetext{
${ }^{1}$ Institute for Society and Business, Roskilde University, Denmark. Email: obruun@ruc.dk
}

This article has been accepted for publication and undergone full peer review but has not been through the copyediting, typesetting, pagination and proofreading process, which may lead to differences between this version and the Version of Record. Please cite this article as doi: $10.1111 /$ dpr.12432

This article is protected by copyright. All rights reserved. 
since 1975. Despite the international focus on 'social safeguards', ethnic minority people lose access to forest resources while most are trapped in poverty. The findings add to a growing literature critical of REDD+.

Policy implications

Current economic growth priorities have negative social and cultural impacts of such magnitude that they go beyond acceptable trade-offs, as much as they threaten the very objective of climate-mitigation projects. Both the basic safeguards instruments (a rights-based approach, the FPIC process, and a broad range of stakeholder engagements) and the global VGGT standards are in practice set aside by the authoritarian state. This tends to be commonly available knowledge, and it would seem that international donors observing the mandate of global climate deals have become insensitive to rights. However, in order to secure continued backing to global climate-related funding mechanisms, improved monitoring is urgently needed.

Keywords: Development interventions, forests, highland development, indigenous peoples, REDD+, safeguards, Vietnam

\section{Introduction}

Global climate-related mechanisms tend to assume a general consensus and apply a tabula rasa perspective on interventions, as if society were characterised by uniformity and harmony. This is particularly clear in interventions that directly or indirectly draw on the technical and universalist formulations of the United Nations International Panel on Climate Change (IPCC). ${ }^{2}$ By referring to 'human and natural systems' and generalised 'socio-economic processes', global institutions are increasingly criticised on the grounds of their state-centred and depoliticising framings (Marino \& Ribot, 2012; Zink, 2013; Schulz \& Siriwardane, 2015). Moreover, discursive traits like 'Climate-change impacts are expected to exacerbate poverty in most developing countries...' (IPCC, 2014, p. 20) are wide open to misapplication: they may in fact provide poorly performing and/or authoritarian governments with convenient social-to-natural projections, and in the worst case may act as a cover-up for discriminatory policies that result in poverty and inequality.

\footnotetext{
${ }^{2}$ Risk of climate-related impacts results from the interaction of climate-related hazards (including hazardous events and trends) with the vulnerability and exposure of human and natural systems' (IPCC, 2014, p. 3).
} 
This article examines the consequences of authoritarian and technocratic development interventions for the highland population of Vietnam. With the REDD+ programme for global climate change mitigation intervention as the tangible case, the article demonstrates how this programme silently becomes a tool for state-centred development and ethnic assimilation in the hinterlands, in practice indistinguishable from other government programmes for highland development in the post-1975 era. The article argues that the donor community is in fact well aware of this deviation, but hesitant to retreat and admit to another development failure, and furthermore somehow covertly condones Vietnam's technocratic development plan despite the obvious sacrifices for the highland population.

The critical aid literature emerging from anthropological and general debate since the 1980s highlights the contradictions necessarily faced by climate aid, however well-intended. ${ }^{3}$ First, a broad and now classical field of studies has shown how any development intervention tends to expose existing conflicts and sharpen divides regarding development logics, aspirations and moralities between 'developers' and those 'to be developed'. For instance, there are both potential and real-life contradictions between the labour, market and land-use strategies of peasants and primary producers, and the universalist thinking of development organisations (Sardan, 1988; Sardan, 2005; Mosse, 2011). Building on a succession of studies on peasant economics (Chayanov, 1966; Boserup, 1965; Dalton, 1967; Scott, 1976), early criticism pointed out how big ' $\mathrm{D}$ ' developers ignored local knowledge and distinct peasant and tribal producer logics, which often comprise labour rather than land optimisation, strategies of economic diversification, and overall risk minimisation (Sardan, 1988; Long \& Long, 1992). Moreover, a long time-series of studies spotlighted the inherent mechanisms of agricultural diversification in the modernisation process; in poorer countries this essentially creates two distinct sectors of farming and forestry with separate logics. Capital accumulation linked to global markets and to developmental states' export-driven economic growth models engulfs ever greater land areas. At the same time, large numbers of traditional small-scale producer households struggle on, but are increasingly forced into complementing farming with wage labour (Geertz, 1963; Long, 1977; Bernstein, 2006).

\footnotetext{
${ }^{3}$ This focus at the same time shuns the most radical populist, participatory and bottom-up perspectives (see Lewis \& Mosse, 2006, p. 3).
} 
Second, the discontinuities of interests, values, knowledge and power in development interactions have been continuous subjects of study. In anthropology, this quite obviously fed into a wider cultural and epistemological rejection of a singular modernity in favour of a broader range of cultural styles, techniques and voices, including the denial of unitary theories of progress and rationality (Friedman, 1994; Gardner \& Lewis, 1996, p. xv; Long, 2001). Both neoMarxism's theoretical failure adequately to address local diversity (Booth, 1995) and the high modernist utopian development experiments that inevitably failed or reverted to authoritarian nationalism (Scott, 1998, 2006), brought lasting attention to the social and cultural dimensions of development (Crewe \& Harrison, 1998; Long, 2001). These dimensions were crystalized into key concerns for local participation, gender, awareness of social and cultural complexities, and respect for local knowledge (Gardner \& Lewis, 2015, p. 91). Most crucially, despite the many interacting perspectives that evidently thrive within development practices (Grillo \& Stirrat, 1997), aid efficiency entails almost by definition aligning aid interventions with statist perspectives and economic growth targets. This easily contradicts the ecologically embedded production tactics of socially and geographically marginalised groups of traditional farmers, nomadic pastoralists, and forest dwellers. In the highlands of Vietnam, these contradictions further tend to follow ethnic fault lines, along which historical state formations ingrained in 'hydraulic' production systems and associated identities are poised against mostly small-scale, state-avoiding forest-farmer communities (Rambo, 1995; Scott, 2006; Sikor, 2011; Bruun, 2017).

Third, there is enduring debate on what 'Development', besides its stated purpose, brings about in the form of side effects, hidden agendas or unintended consequences (Gow, 1996; Rist, 1997; Dichter, 2003; Easterly, 2013). Particularly relevant is a group of studies on the unspoken logic of development interventions, which despite evident failures still have important instrument effects (Ferguson, 1990; Mosse, 2005; Li, 2007). Development has become a dominant discourse through which power is diffused, and when donors willingly adopt nation states' discourses on the traditional and backward ways of their marginal populations, these people are easily turned into history-less subjects of imperative interventions. As most astutely pointed out by James Ferguson, state and donor interventions continue despite failures to carry out decentralisation, which effectively expand bureaucratic state power, while at the same time depoliticising poverty and the state (Ferguson, 1990, p. 256). In parallel, a long process of forest restoration in the Asia-Pacific region has tended to consolidate the control of state agencies and corporate actors 
over 'degraded' forest landscapes, often resulting in the displacement of rural communities (Barr \& Sayer, 2012).

In addition to these structural dilemmas of development, interventions in authoritarian regimes pose generic challenges: the authoritarian state acts as a powerful third and interlocking force between aid donors and recipients. ${ }^{4}$ The state manifests itself through controlling all practical and material issues of aid-recipient identification, funding allocation, access, and monitoring. This inevitably raises ethical concerns of how to ensure common principles of equity and representation under wilful state agency. With a constitutional monopoly on organising and representation, authoritarian states seldom allow alternative, bottom-up representation by trade unions, communities, ethnic groups or civil society. We are, in fact, currently witnessing a global trend of such regimes tightening their grip on non-state and foreign-funded actors, and at the same time narrowing public debate (Diamond \& Plattner, 2016; Rutzen, 2016; Freedom House, 2017; Economist, 2018). As a consequence, a new layer if not a wall is added to common barriers between 'developers and those to be developed', as the one-party state manages all exchanges, material (money and goods) and non-material (communication, voice and representation), between the international donor community and the rural poor. ${ }^{5}$

At the same time, all development interventions are fraught with trade-offs, typically between economic, environmental and social inclusionary bottom lines, such as continually negotiated and balanced in donor-recipient relations. Another set of trade-offs relates to the allocation of international aid according to complex political and bureaucratic processes, in which objective needs are often subjugated to donors' colonial histories and geo-political self-interests (Hoeffler \& Outram, 2011). We do not challenge developing countries' right to formulate their own needs, but call for a differentiated perspective that considers poorly represented groups in accordance with appropriate international benchmarks.

\section{Context and methods}

\footnotetext{
${ }^{4} \mathrm{~A}$ definition of authoritarianism may draw on Carl Juan Linz' four qualities: political alignment of groups and institutions, an emotional basis for legitimacy, constraints on social mobilisation, and vaguely defined executive power (Linz, 1964).

${ }^{5}$ Concurrently, the purported successes of authoritarianism in generating economic development and eradicating poverty are the subject of continued debate, particularly concerning the price to be paid in loss of basic freedoms (Sen, 1999; Easterly, 2013, pp. 17-42).
} 
The present study took place in Lao Cai, a mountainous province in the northwest of Vietnam bordering on China's Yunnan province. Lao Cai has an area of $6,384 \mathrm{~km}^{2}$ and a population of roughly 700,000 people, of which $64 \%$ belong to 27 registered 'ethnic minority' groups. It is one of the poorest provinces in Vietnam with $65 \%$ living under the poverty line, and chosen as one of six provinces in the national REDD+ programme. The study builds on a comprehensive household survey on REDD+ activities and livelihoods in three communes (two villages in each, 148 households in total): Long Khanh and Ban Bon communes in Bao Yen district, and Ban Cam commune in Bao Thang districts. ${ }^{6}$ The survey was supplemented with in-depth interviews among villagers, extensive talks with governments (People's Committees) at provincial, district and commune level, and various observations and interviews across the province (Bao Yen, Bao Thang and Sa Pa districts). It also draws on studies and interviews in other provinces and in Hanoi conducted over many years. The article is based primarily on empirical enquiry and a nonnormative approach in order to examine how development rhetoric relates to outcomes on the ground.

Historically, the Lao Cai region was characterised by dense mountain forests, high biodiversity, and a complex mix of mostly forest-dwelling ethnic groups, some of which originated in China. Only the present Lao Cai city has had permanent settlement as a trading post since ancient times, while Chinese, Vietnamese and various ethnic minorities fought for regional control. ${ }^{7}$ Although the province is still registered as having $44 \%$ forest cover (minimum $10 \%$ canopy cover), a state of affairs symptomatic for the Vietnamese highlands is that nearly all forest is either highly degraded (much of which with little actual growth), or belongs to the categories of 'production forest' and 'protection forest', of which most is planted. Even in the picturesque Hoang Lien National Park, classified as a special-use forest and considered one of the country's top biodiversity centres, only $12 \mathrm{~km}^{2}$ of forest remains, as a result of anthropogenic pressure. Grass, bushes and small trees are seen on large swaths of land otherwise devoid of forests, and large areas are used for cash-crop cultivation. ${ }^{8}$ Lao Cai has been subject to immense land-use

\footnotetext{
${ }^{6}$ The household survey was conducted in cooperation with the Vietnam National University of Agriculture, Hanoi, which also hosted the research.

${ }^{7}$ In 1463 it was established as the northernmost capital of the Viet Kings under the name Hung Hoa, and in 1889 came under French colonial control as an administrative centre and garrison town.

${ }^{8}$ Overall, $0.6 \%$ of Vietnam's forests are assessed as primary forest (USAID, 2013) and many observers rate the country's biodiversity to be at a critical threshold (Brunner, 2012; Ortmann, 2017).
} 
changes, reflected in both the habitation patterns and the economic strategies of especially ethnic minority people (Turner \& Michaud, 2008).

The surveyed districts of Bao Thang and Bao Yen embrace the main traffic arteries between Lao Cai city and Hanoi, with district centres located respectively $30 \mathrm{~km}$ and $80 \mathrm{~km}$ from Lao Cai. The villages to which we had access are still dominated by ethnic minorities (Dao, Hmong, Giay, Tay, San Chay, Nung), but clearly form part of a frontier region for Kinh Vietnamese expansion: increasingly, new settlers, businesses, technology and landscape transformations are displacing traditional mountain-forest farming.

\section{Global discourses versus local complexities: Fieldwork in Lao Cai}

The REDD+ programme was developed by Parties to the United Nations Framework Convention on Climate Change (UNFCCC) as a voluntary climate change mitigation approach, supported among others by the World Bank Forest Carbon Partnership Facility (FCPC). The REDD+ programme was designed as a set of policy approaches and incentives to reduce emissions from deforestation and forest degradation in developing countries such as Vietnam (UNFCCC, 2011, Section C). ${ }^{9}$ However, with obligations to be met 'as deemed appropriate by each Party and in accordance with their respective capabilities and national circumstances' (UNFCCC, 2011, Section 70), both the core wording and the statist perspective may lend a helping hand to technocratic governance.

So, let us begin with how the global aid community conceives social protections in these programmes. The IPCC early on acknowledged that 'special attention needs to be given to indigenous peoples' and to issues of equity (IPCC, 2007, 4.7.2). The UN partners that initiated UN-REDD also acknowledged that because programme areas are likely to feature or include the territories, ancestral domains, resources and source of livelihoods for indigenous communities' (UNFPII, 2011, p. 2), specific guiding principles apply. Following the 2010 Cancun agreement on safeguards, both the UN and the World Bank have developed strong and detailed guidelines specifically for Indigenous Peoples and 'other forest-dependent communities.' The joint principles include following a human rights approach and adhering to the United Nations

\footnotetext{
${ }^{9}$ The programme requires participating countries to reduce emissions from deforestation, reduce emissions from forest degradation, conserve forest carbon stocks, sustainably manage forests, and enhance forest carbon stocks.
} 
Declaration on the Rights of Indigenous Peoples (UNDRIP), although the two organisations differ on a range of instruments and procedures. ${ }^{10}$ Taken together, the three primary instruments for securing the protection of indigenous peoples' interests are a rights-based approach (based on international instruments like UNDRIP), the Former Prior Informed Consent (FPIC) process, and a broad range of stakeholder engagements, consultations and representations depending on the funding agency.

The following sections examine how these three instruments are used in practice. Starting at the national level, the Party-state does not recognise Indigenous Peoples and the related rights complex, but only refers to 'ethnic minorities' in the unified and sovereign state of Vietnam. Forest projects indisputably include 'forest dwelling communities' with traditional forest-based livelihoods, but because all land belongs to the state, customary rights are neither recognised de jure nor considered de facto. Furthermore, in practice 'communities' in Vietnam refer to the formal state administration of districts, communes and villages, all under Party (People's Committees) control (Bruun \& Olwig, 2015). 'Community-based forest management' is introduced as an experimental term, but does not alter the local political or legal set-up. Consequently, international aid parlance like 'the customary land rights of indigenous peoples' communities should be integrated into REDD+ programs' includes terms that have no equivalents in Vietnamese law and policy. The World Bank, UN and bilateral donors are of course well aware of this schism, but adopt a pragmatic approach, since, as pointed out in one evaluation, 'it is not appropriate to insist on international norms that may not be implementable' (UN-REDD, 2012, p. 12). Similarly, the FAO/CFS global VGGT guidelines for securing rights to land, forests and fisheries, which are seen as ground-breaking and far-reaching contemporary benchmarks and to which both the UN and the World Bank adhere, are not endorsed by Vietnam. ${ }^{11}$

\footnotetext{
${ }^{10}$ The UN demands adherence to ILO Convention 169 and a range of other international instruments to Free, Prior, and Informed Consent (FPIC), and to the broad representation of indigenous peoples (UNFPII, 2011, pp. 2-3; World Bank, 2012a). The World Bank has its own Operational Policy on Indigenous Peoples (4.10), which includes Free, Prior and Informed Consultation, but which also clearly specifies screening and planning for Indigenous Peoples' issues as well as action plans for legal recognition of customary rights (World Bank, 2012a, annex 3).

${ }^{11}$ The Voluntary Guidelines on the Responsible Governance of Tenure (VGGT) were endorsed by the Committee on World Food Security (CFS) in 2012. While all major countries in Southeast Asia are members of CFS, Vietnam, Laos and Myanmar are not. The FAO recently arranged a VGGT 'awarenessraising' workshop in Vietnam.
} 
The donor literature nevertheless praises Vietnam's FPIC approach (UN-REDD, 2012), although it is virtually impossible to monitor in practice. Ethnic minority areas in Vietnam are either heavily restricted or permanently out of bounds for research, and even REDD+-designated areas are not generally open to scrutiny. It takes months of preparation, a high-ranking Vietnamese research partner, public security clearance and the express consent of the local authority, which also scans pre-submitted questions. The gatekeeping procedures for research continue at district level, where local officials take you through lengthy meetings in the standard Red-Flag-and-HoChi-Minh-bust atmosphere, and similarly at commune level. Eventually, village officials will guide you to pre-selected households and often sit in on interviews, only gradually loosening their grip on the interaction.

The present research area is inhabited by the Dao, Giay, Nung, Hmong and other mountainforest and highland agricultural people of Lao Cai, resettled into single or multi-ethnic villages but still mostly residing in traditional wooden stilt houses. The vast majority are 'poor' or 'nearly poor', deprived the natural wealth of the forest and their traditional livelihoods since valuable forest is long gone. Most of the adult population remains relatively disconnected from Vietnamese society and articulates little desire to engage. The people appear mostly shy, subdued, even fearful of contact with outsiders, and their ethnic interaction with the Kinh Vietnamese is perceptibly strained by historical and current animosities. To the outsider, the common Kinh Vietnamese attitude to highland minorities appears disrespectful.

Today there is a general logging ban in the remaining forest. Forest Management Committees form part of the provincial government administration, and Forest Protection Teams set up at village level are not under separate REDD control. Interviews with villagers revealed that the FPIC process involved a provincial agricultural officer arriving to inform them about REDD+ at a regular village meeting to which households must send one member; usually the women go. The process was in principle completed in 30 minutes to an hour, explaining the project in Vietnamese, which many adult villagers understand poorly, and stressing that villagers would benefit from new joint funding and direct payments. There are no local ethnic minority-based bodies since the state retains a monopoly on organising, and thus no space for reverse representation. Crucial decision-making on the selection of REDD+ sites takes place at centralgovernment and provincial levels, and the fact that such meetings are used mainly for communication purposes is confirmed by other studies (McElwee, 2017). Several villagers also told us that the village headman had in fact refreshed their recollection of the FPIC meeting just 
before our arrival. Nonetheless, when surveyed about their awareness and expectations of REDD+, the results are set out in Table 1.

Table 1. Survey excerpt on REDD+ awareness and expectations. All values in percentages: total (T) for survey and separate values for Bao Yen district, Long Khanh commune (BY1), Bao Yen district, Xuan Hoa commune (BY2), and Bao Thang district, Ban Cam commune (BT)

\begin{tabular}{|c|c|c|c|c|c|c|c|c|c|c|c|c|}
\hline \multirow{2}{*}{$\begin{array}{l}148 \text { households in three } \\
\text { communes (two districts) }\end{array}$} & \multicolumn{4}{|c|}{ Yes } & \multicolumn{4}{|c|}{ No } & \multicolumn{4}{|c|}{ Don't Know } \\
\hline & $\mathbf{T}$ & BY1 & BY2 & BT & $T$ & BY1 & BY2 & BT & $T$ & BY1 & BY2 & BT \\
\hline $\begin{array}{l}\text { Have you ever heard about } \\
\text { REDD? }\end{array}$ & 73 & 84 & 63 & 72 & 27 & 16 & 37 & 28 & & & & \\
\hline $\begin{array}{l}\text { Do you believe you could benefit } \\
\text { from a REDD programme? }\end{array}$ & 62 & 78 & 51 & 52 & 12 & 5 & 14 & 20 & 26 & 10 & 35 & 28 \\
\hline $\begin{array}{l}\text { If REDD is implemented, do you } \\
\text { think you can use the forest as } \\
\text { before? }\end{array}$ & 9 & 12 & 6 & 8 & 83 & 79 & 85 & 88 & 8 & 9 & 9 & 4 \\
\hline $\begin{array}{l}\text { Would you like to own a forest } \\
\text { plot? }\end{array}$ & 77 & 69 & 82 & 80 & 10 & 10 & 6 & 20 & 13 & 21 & 12 & 0 \\
\hline
\end{tabular}

The REDD programme was initiated in the three communes at different times, starting in Ban Cam in late 2014, Long Khanh in August 2016, and Ban Bon in late 2016. Interviewing confirmed that, despite basic awareness (72\% having 'heard about REDD') and general approval of the overall aim of forest protection, knowledge of project activities and long-term objectives varied considerably. Some associated REDD with forest protection and patrolling, others with livelihood diversification, yet others with garbage incinerators. However, using the FPIC process primarily for communication purposes, this is not unique to Vietnam but is reported across the broad range of REDD+ countries (Barletti \& Larson, 2017, see below).

Land rights were never part of the communication, and everyone interviewed admitted to the reality that all land is controlled by the state. Instead, the nationwide principle of 30-year lease terms for small plots of agricultural land (Red Book registration) now applies and provides villagers with a basic subsistence, as described below. Although villagers' expectations were that 
they would benefit economically, ${ }^{12}$ a vast majority (83\%) believed that they can no longer access the forest as previously. Not surprisingly, many people in subsequent interviews associated REDD with other state programmes intended to restrict and police remaining forest areas: preREDD afforestation campaigns were also known to disrupt customary land-use systems despite community-based forest-management rhetoric (Clement \& Amezaga, 2009). Not least, villagers associated REDD with the central government Payments for Ecological Services (PES) programme, which pays villagers a small sum for participating in forest-protection teams. Thus, from the perspective of beneficiaries, both REDD and PES appear to serve the same purpose: not of enabling forest-dwelling people to sustainably manage the forest, but essentially of keeping them out. Again, however, comparison across REDD+ countries reveals that disruption of land-tenure systems is a common grievance, particularly in the absence of formally binding rights mechanisms (Corbera et al., 2017; Jodoin, 2017). The sums to be paid out, whether derived from PES or REDD, are around 200,000 VND (9 USD)/ha/year to be shared in the forestprotection team, which is a pittance compared to the potential timber value of forest land (where 10-20 tons of wood/ha/year are added) if properly managed. Furthermore, villagers have not yet received payment from either programme. The household survey also indicated a broad concern about payments for REDD or PES services 'passing through too many hands'. Village headmen are in principle locally elected, but answers from villagers indicated low trust in authorities, especially those beyond the village, which are almost exclusively staffed by Kinh Vietnamese.

Table 2. Perceptions of forest restrictions, in percentages (Bao Thang and Bao Yen combined,

\section{8 households)}

\begin{tabular}{|l|l|l|l|l|}
\hline $\begin{array}{l}\text { Are you allowed inside the } \\
\text { forest for: }\end{array}$ & Yes & No & $\begin{array}{l}\text { With per- } \\
\text { mission }\end{array}$ & Don't know \\
\hline - hunting and trapping? & 2 & 71 & 1 & 26 \\
\hline $\begin{array}{l}\text { - collecting timber and non- } \\
\text { timber forest products? }\end{array}$ & 7 & 54 & 11 & 26 \\
\hline - grazing livestock? & 10 & 60 & 8 & 22 \\
\hline
\end{tabular}

\footnotetext{
${ }^{12}$ Evaluations have warned against raising too high expectations (UN-REDD, 2012).
} 
In the surveyed villages, shifting cultivation (swidden agriculture) has been finally abandoned within the last five to ten years, which several villagers claimed undermined their food security. In Bao Thang district a few groups still practise shifting cultivation while in Bao Yen district, which stretches $30 \mathrm{~km}$ eastward into the mountains, it is still widely practised by various groups, to the outspoken dismay of provincial and district authorities. During formal meetings they respectively called it 'the greatest source of forest destruction' and 'primitive and backward', at the same time repeating central government rhetoric that the minorities are hard to reach and 'resist modernisation' (vietnam-redd.org). ${ }^{13}$ Denigrating language and stereotyping attitudes towards ethnic minorities, such as have been continuously documented in both ethnographic and donor literature (Hickey, 1982; ADB, 2002; World Bank, 2009; Nhinh \& Bruun, 2013; Salemink, 2011), persist in contemporary Vietnam. Similarly, the relevance of traditional highland farming is rejected outright by authorities at all levels, even though a range of international and recent Vietnamese academic literature has highlighted its relative ecological merits (Fox et al., 2000; Fox et al., 2014; Bruun \& Ngoc, 2018). Provincial authorities further complained that only the young ethnic minority people speak Vietnamese and that many parents force their children out of school. Conversely, many interviews suggested that fees for secondary school in particular were preventing many poor families from keeping their children in school beyond primary level. Interviews with parents and schoolchildren further confirmed that schools in the two districts teach only Vietnamese language, culture, history and values, indicating an approach to ethnic minorities as history-less subjects of imperative interventions.

\section{New opportunities in the highlands}

From a lowland Vietnamese perspective, the highlands are perceived as lands of new opportunities, even as empty spaces waiting to be developed. In principle, ethnic minority people should also be able to benefit from economic growth in their lands, providing new markets and new jobs. Social safeguards are key to assuring that forest-dwelling people retain at least parts of their traditional livelihoods in this process of economic transformation. They become all the more important in an atmosphere of opportunism, where local decision-making and resource-exploitation activities often evade central control. However, a 2016 UN evaluation

\footnotetext{
${ }^{13}$ The common approach to participation corresponds to what both Chambers (2005, p. 86) and Arnstein $(1969,2017)$ characterise as the bottom rung of the participation ladder, seen respectively as basic 'information sharing' or as outright 'manipulation', involving participants being 'educated' or 'cured'.
} 
of Vietnamese safeguards based on a range of academic and local material found that 'implementation is limited at best', and reacted to the 'absence of a robust and independent framework for monitoring and evaluating implementation of policies and the actions of public officials' (UN-REDD 2016b, p. 6).

Conditions on the ground are changing rapidly in this frontier region and the state appropriation and exhaustion of the forest already seems a fait accompli. According to local people, forest resources in Lao Cai province were extensively exploited or destroyed during the 1979 ChineseVietnamese war. After unification and war, state forestry companies and foreign contractors swept across Vietnam and felled the most accessible hardwood species. State companies producing fine-hardwood chopsticks and furniture for export further exploited valuable resources in Lao Cai by means of quota deliveries from village-production teams, until the hardwood was exhausted and the factories ceased production. Likewise, in Lao Cai province as elsewhere in the highlands, state and military units as well as state-endorsed companies have privileged access to forest areas for forestry plantations, timber-processing plants, hydropower construction, and mining such as for copper, molybdenum and apatite. For instance, Vinh $\mathrm{Ha}$ electricity company runs a hydropower plant and controls a huge area across several districts, and in Bao Yen district a state forestry company produces plywood sheets for export to South Korea on a 10, 000ha acacia forest concession, while at the same time providing jobs for 200300 people.

As a result of these conditions there is now a striking wealth gap in the province. National and local businesses and various state units tap into the natural wealth of the highlands, the growing trade with China, and the rapidly growing tourism industry. In the capital city of Lao Cai, topmodel Mercedes and Porsche cars abound in the streets with their ill-reputed drivers, and countless fashion stores, cafés and expensive restaurants cater to the new Vietnamese elite.

\section{What REDD projects contribute}

Let us for a moment take a look at the contents of district and commune-level projects funded by REDD, such as expounded by district People's Committees. Taking Ban Cam commune, Bao Thang district, as an example, a total of $1000 \mathrm{~m}$ VD (50,000 USD) was allocated when the project started in late 2014 . Of this, $60 \%$ went to a livelihood-diversification fund, $30 \%$ to forestplantation funding, and $10 \%$ to training, coordination and control. However, livelihood 
diversification was already part of a long-standing range of previous government programmes. ${ }^{14}$ Within the REDD programme, households were organised into 'user groups', each with access to loans worth 20-80 m VD (1,000-4,000 USD) at 6\% interest per year (nothing is given out for free) for investment in livestock, mainly chicken and pigs. In addition, the commune provided training to user groups. However, bad luck struck: the price of pork soon fell dramatically, and the chickens contracted disease and were unsellable. Consequently, many locals reportedly went back to pineapple and sugarcane production for sale along the roadsides. Furthermore, those who conducted forest patrols and replanting in protected forest never received direct 'resultsbased payments' from foreign donors as was anticipated, and there was general disappointment with REDD.

Across the three communes, a range of other small project funding went into pigs, goats and ducks, or into loans for planting new cash crops like cinnamon, machiato and fig trees as part of the overall central government initiatives for livelihood diversification. However, in Long Khanh commune, Bao Yen district, REDD funding was reportedly used for constructions like a new communal hall, a water tank, toilets and small waste incinerators, all items usually considered key features of the NRDP. The forest-plantation funding may go into commune forest replanting or into loans for private plantation forestry as mentioned above, which was also part of many previous government programmes such as the 327 .

Forest cover in Bao Yen and Bao Thang districts is statistically high (70\%) but translates into 'plantation forest' (38\%), 'protection forest', with various degrees of degradation, and land that is practically barren despite being classified as forest. Primary forest is long gone and around villages. The remaining patches of secondary forest are heavily degraded despite a general logging ban. These areas are deprived of both valuable tree species and wildlife as a result of over-exploitation combined with a lack of protection and sense of ownership, thus reflecting a long race to the bottom. There was little incentive and few means to protect forests after they were declared state property and the customary users were evicted. Villagers still retrieve firewood and some timber for house building and repairs, but explained that they can no longer find high-grade insect-resistant hardwood. Other forest uses are now limited: some bamboo shoots, medical plants and mushrooms may be collected. Hunting and trapping used to be

\footnotetext{
${ }^{14}$ Livelihood diversification was included in the 327 and 661 reforestation programmes, the New Rural Development Program (NRDP) and its 2017 extension, and the Comprehensive Poverty Reduction and Growth Strategy.
} 
common, but the landscape is now mostly devoid of living creatures, big or small. As an indicator, just a few instances of crop damage from sparrows, chipmunks and in a single case, wild boar were reported in surveys covering a five-year period.

It is evident from this and other REDD projects visited in Vietnam that they are located in areas that are in a consolidation phase in the transition to farming and agro-plantation growth, thus contributing to the instrument effect of state interventions. Since the reform era, the overwhelming policy emphasis has been on private plantation forestry, and REDD is not seen to alter these priorities. ${ }^{15}$ Conversely, international funding would hardly be permitted in areas where ethnic minorities are still practising swidden agriculture and where ethnic struggle is imminent. Reports from elsewhere in the highlands indicate that in the initial stage of transformation, the simultaneous rejection of customary land rights and the institution of state ownership within a high-corruption environment contributed to the creation of 'ownerless' forests, in reality with free access for the most powerful actors (Hoang, 2011, p. 111; Sikor, 2011). Lawlessness created a state of affairs where competing actors may cut down the forest as a means of staking land claims (Kemf \& Vo, 1999; Hoang, 2011; Bruun, 2017). The subsequent partial land privatisation created privileged access for state entities, party-affiliated entrepreneurs, and large private-sector actors, all operating in an atmosphere of sustained ethnic minority stereotyping, and facilitated by local environmental corruption (ADB, 2002; Vien, 2012, pp. 8-10; Nhinh \& Bruun, 2013); under these circumstances illegal logging may even facilitate land transformation (Bruun, 2012, p. 256). In combination, these processes dealt a brutal blow to ethnic minorities who previously relied merely on informal, unauthorised access to their ancestral lands (UN-REDD, 2016a, p. 9). Even today, many local people refuse to obtain legal documents, saying 'why should we bother, we have always lived here!'16

The minority people of the researched districts of Lao Cai all confirm that from the mid-1990s their ancestral land has been taken. In particular, many households report having lost forest land after 2003/4, when the new land law came into effect and land certificates were first issued. By means of the state forest-classification system (protection, special use and production forests),

\footnotetext{
${ }^{15}$ Researchers connected to this project visited REDD+ offices and pilot sites in Bac Kan, Lam Dong and Lai Cai. Interviews with the head of the national REDD+ office in January 2016 confirmed plantation forestry to be a key development objective.

${ }^{16} \mathrm{~A}$ commonly recognised risk is that REDD merely adds new rules for worthless forest, whereas no protections apply to valuable old forests where ethnic minorities live: REDD may help those who cut the forest (Barletti \& Larson, 2017).
} 
forest land was subsequently turned over to large forestry contractors and hydropower entities, or developed into agricultural land for new settlers. Several people reported being heavily fined or otherwise punished for continuing to use their ancestral land, to the effect that they simply stay away. Continuing a range of post-war highland development programmes, the cornerstones of state policy are still complete sedentarisation of ethnic minorities ('fixed fields, fixed residence'), livelihoods based on paddy cultivation, and agroforestry plantation development (Rambo et al., 1995; Duncan, 2008; Sikor, 2011). Agricultural land-use certificates for 30-year leases are issued to the effect that most villagers now depend on the small leased plots for paddy, vegetables and small livestock. The plots are usually around 1 sao (360 sq. m.) per adult, which virtually turns them into common Vietnamese peasants and provides only a meagre subsistence. For instance, a household of five may have 1000 sq. m. and one of eight has 1500 sq. m. and so forth. Yet people cannot even be sure of keeping their land after the 30-year term expires. This is the ubiquitous Vietnamese farming model, and the old forest inhabitants must compete everywhere for land with new Kinh Vietnamese settlers. Thus, even in this sparsely populated province, agricultural land is scarce and few have access to extra land. ${ }^{17}$ Most households are in reality stuck in poverty, and just a small segment of Vietnamese-speaking ethnic minority people have been able to exploit new economic opportunities, such as starting businesses beyond small village kiosks.

The situation with regard to forest land, the object of REDD+ programmes, is similar. Communelevel authorities in principle decide on access to land, though conflicts of authority have arisen between conventional People's Committees and new provincial-based REDD bodies. Unsurprisingly, considering their cultural bonds with the forest, most households in the surveyed villages (see Table 1 above) would prefer to have their own forest land. However, strict requirements and 50-year lease terms, together with many instances of forest being reclassified and given to new owners, make people afraid of losing both land and investments, and there may be little incentive for long-term investments such as in hardwood. As a result, forests now play a diminishing role in their livelihoods and lifestyle (see Table 3).

Table 3. Experienced change in household income during the last five years, and the perceived main causes, Bao Thang and Bao Yen districts (no. of households)

\footnotetext{
${ }^{17}$ Moreover, in some highland minority areas land tenure is still unsettled for reasons of inadequate measuring, competing claims, or state units' interference; in one hamlet in Bao Yen district only 6 out of 22 households had received land certificates.
} 


\begin{tabular}{|l|l|l|l|l|l|l|l|}
\hline n=148 & Total & $\begin{array}{l}\text { Agriculture, } \\
\text { crops, new } \\
\text { methods }\end{array}$ & $\begin{array}{l}\text { Domestic } \\
\text { animals }\end{array}$ & $\begin{array}{l}\text { Forestry, } \\
\text { swidden/ } \\
\text { plantation }\end{array}$ & $\begin{array}{l}\text { Wage and } \\
\text { migrant } \\
\text { labour }\end{array}$ & $\begin{array}{l}\text { Trade, } \\
\text { business } \\
\text { and repair }\end{array}$ & $\begin{array}{l}\text { Social } \\
\text { issues, } \\
\text { disease, gov. } \\
\text { support }\end{array}$ \\
\hline $\begin{array}{l}\text { Positive } \\
\text { change }\end{array}$ & 67 & 22 & 3 & 4 & 14 & 5 & 9 \\
\hline $\begin{array}{l}\text { Negative } \\
\text { change }\end{array}$ & 19 & 7 & 2 & 2 & 1 & & 7 \\
\hline Neutral & 53 & & & 1 & & & \\
\hline
\end{tabular}

Table 3 shows how villagers interpreted the development of their livelihood base and the main causes of change (not all villagers qualified the reasons for change). Although a significant number of households had experienced rising incomes (45\%), this is from a very low baseline and the data may also indicate social differentiation (42\% reporting no change and $13 \%$ reporting falling incomes), which is a common occurrence in the reform era. Many households reportedly achieved better farm incomes through improved and new crops, new machinery or new domestic livestock. However, interviewing also confirmed the food-insecurity risks involved in high-yielding rice varieties compared to traditional crops (Bonnin \& Turner, 2012). Many households had lost parts of their crops to rice pests in recent years, presumably resulting from monocropping on unsuitable land and from flooding, which is exacerbated by deforestation. Another leading trend is the huge pressure on all farming households in Vietnam to engage in wage and migrant labour as a way out of poverty. Most ethnic minority households in the fieldwork area explicitly resist migrant labour, seen as the irrevocable surrender to Vietnamese culture, and they are fully aware that traditional state-avoiding strategies may be equivalent to living in poverty. However, a great many people take local work of all kinds; for instance, in Bao Yen district many young Dao and other minority people work at the local plywood factory, which pays $4 \mathrm{~m}$ VD (175 USD) per month for a 48-hour week.

Table 3 corroborates that the forest is mostly obliterated and, apart from small private forest plots, definitively out of the hands of local people as a result of state interventions. Overall, in Bao Thang and Bao Yen, approximately $25 \%$ of interviewed households had legal use rights to forest land, and in a similar survey in Lam Dong province merely $10 \%$ of households were allocated forest plots. Small private plantation forest plots, typically for acacia, are part of the development model throughout the highlands. Farmers may become eligible for 'Green Book' certificates to patches of forest land, typically $2-3$ ha and in a few cases up to 5 ha. They may 
plant acacia, figs or cinnamon trees, mixed with crops of cassava or maize, on the condition that they plant a specified number of tree seedlings (1600/2500 according to species) per ha within the first year, or they lose the land. In disregard of local production techniques, this ensures that local people will establish plantation forestry and contribute to national economic growth, while effectively blocking a return to shifting cultivation. In any case, the Party-state issues shrewd, growth-oriented policy directives that place great emphasis on individual capacity and selfcontribution (Bruun \& Olwig, 2015). State loans and benefits are usually paid out retrospectively, so that economic opportunities are offered to the better-off households who can invest in seedlings. Thus, when households answered that they wished to own forest land, this should be seen against the requirement of intensive plantation forestry, and many households in surveys and interviews expressed the view that they would in fact just capitalise on the forest and sell their plots. Moreover, procedures for legal access are perceived as inscrutable: households must obtain a letter from the Forestry Management Committee and take it to the commune People's Committee to apply, and allegations of nepotism and corruption abound.

At district and commune levels, political and agricultural authorities dominate, although conflicting interests and competing authority are endemic to the system. ${ }^{18}$ This is particularly clear between the old provincial Financial and Investment Department and the new provincial REDD Office, despite both operating under the auspices of the Ministry of Agriculture and Rural Development (MARD). While donor pressure pushes for diversification in REDD+ activities, at the local level economic interests gain the upper hand. As noted above, livelihood-diversification policies form part of a range of state programmes which provide small funding to be administered by local government without much distinction between sources. When asked directly at meetings, district and commune People's Committee officials readily confirm that REDD+ is integrated into existing rural development plans, especially the NRDP. Under this scheme, 'sustainability' translates into plantation forestry, higher yields and economic growth, and there is no real backing for the idea that environmental protection should bear a cost. ${ }^{19}$ Pointing to the case of Hoang Liem National Park, which attracts many tourists, both provincial

\footnotetext{
${ }^{18}$ Both the present research and other sources have noted provincial freedom of interpretation and the fragmentation of authority in forest management (Clement \& Amezaga, 2009). In the post-reform Vietnamese state very often new business and provincial interests operate "with little regard to what the formal rules say' (Gainsborough, 2010, p. 481).

${ }^{19}$ Neither is biodiversity an issue for local governments (People's Committees), and environmental protection (under the Ministry of Natural Resources and Environment - MONRE) is now increasingly integrated into MARD forestry organs at district level across Vietnam (Bruun, 2017).
} 
and district authorities unequivocally declared that if patches of forest and scenic landscapes are to be preserved, this will be explicitly for the purpose of generating income from tourist development.

\section{Stakeholders and discourses}

This brings us to the question of non-state actors and stakeholder representation, which is the final aspect of the social safeguards structure. When REDD+ was initiated in Vietnam, every government, civil-society and donor organisation worthy of note in Hanoi became involved in workshops and consultations. To accommodate them, the national REDD+ programme developed a complex management set-up with a steering committee, work groups and subgroups, in which over 100 stakeholders were registered. ${ }^{20}$ However, moving below the national level and beyond the donor-financed workshops, complexity quickly diminishes. There are provincial-level REDD+ offices, which may see representatives from national NGOs in their workshops, but local civil society is not commonly involved. At the local level (district and commune), REDD+ is exclusively managed by government, involving merely the old top-down mass organisations such as the Women's Association and the Veterans' Union.

A range of international NGOs are, or have been, active in Lao Cai, including Save the Children, Oxfam and World Vision, but they rarely operate at the local level. Both the present and previous fieldwork in North Central Vietnam found that NGOs are seldom allowed in. ${ }^{21} \mathrm{~A}$ single ethnic minority representative of CEMA (a state organ) has a seat in the REDD+ Steering Committee, the role of which is vague. As noted on the national REDD+ homepage, 'no local non-governmental organisations have been registered to specifically advocate for the rights of indigenous peoples' (Vietnam-redd.org). ${ }^{22}$ At the same time, state policy towards civil-society actors has toughened considerably since 2013.

\footnotetext{
${ }^{20}$ In Vietnam as elsewhere so many REDD workshops have been held that the Rainforest Foundation UK slammed the World Bank FCPF for allowing almost two-thirds of REDD+ funding until 2016 to go into administration, consulting expenses and transaction costs, 'without a single hectare of forest being saved' (REDD-Monitor, 2016).

${ }^{21}$ Only in the most poverty-stricken rural areas and in some mountain areas may certain NGOs be allowed to operate directly in villages, explicitly under the auspices of local government, such as after the 2009 Ketsana typhoon.

${ }^{22}$ The NGO CERDA was set up with support from NORAD to support indigenous peoples in the REDD+ process, but it no longer appears to be active.
} 
NGOs are crucial actors in social and environmental protection work and advocacy at national level. But the implications of their absence in local society is that their work is only sporadically represented in local and provincial governing bodies. For instance, both survey and interviews showed that in these areas only the original highland people speak affectionately of forest spaces, wilderness and diversity, which indicates indigenous people's potential for forest stewardship. Thus, the government's agricultural monocropping regime is mostly uncontested at the local level, though criticised by both domestic and international observers as being unsustainable (Fortier, 2013; Ortmann, 2017).

Discourses on REDD+ not only decrease in the level of abstraction from higher to lower levels, but also change tone. The national discourse refers to the global goals of climate change, sustainable management, reforestation, and community management, while only scant remarks are found on minorities 'not wishing to integrate'. At provincial level priorities are already shifting, indicating considerable freedom of interpretation: co-management of forests is to be achieved through allocating forest land to local entities. But in the interpretation of provincial MARD officials, a key objective of REDD is explicitly to increase the 'awareness' of the hard-toreach non-Vietnamese-speaking minorities. The latter are accused of bearing the main responsibility for deforestation (secondary and tertiary causes are plantation forestry and infrastructure), and a first priority is to build alternative livelihood strategies such as conventional agriculture and animal husbandry to make them give up their traditional way of life. At district level and down to the commune-level People's Committees, the rhetoric against ethnic minorities for their lack of 'awareness' is hardened and the principle objective of REDD is to redress this. Second, REDD should integrate into the NRDP, which includes the promotion of plantation forestry; and third, REDD should include 'co-management of the forest', essentially by means of PES and other small payments for forest patrolling in order to keep local people out of state and REDD-designated forests.

Thus, global discourses on climate change are silently turned into support for ethnic assimilation and technocratic state planning, and essentially become a tool of authoritarianism. Broad interviewing among local officials corroborated the unchanging character of Vietnamese views of non-economic forest spaces (Jamieson, 1991; McElwee, 2016), including the subjection of REDD to overall state-planning goals and human-management concerns. The only elements in traditional highland agriculture which district authorities acknowledge as being of value are medicinal plants, which sell at a high price to the Chinese, and aspects of livestock rearing. 
Comparison with other REDD contexts shows that such shortcomings are very common, resulting in persistent criticism from indigenous peoples' organisations. For instance, in November 2018, an assembly of Latin American organisations lamented the resistance of many governments to seriously address property rights over land and territory, carbon rights, and participation and consultation issues, while calling for protections, real participation and respect for the FPIC process. ${ }^{23}$ At the same time climate projects under UN-REDD have been implemented for long enough to have generated a substantial academic literature on outcomes and shortcomings. A recent review carried out under the auspices of CIFOR and including 85 journal articles (Barletti \& Larson, 2017) is a harrowing reiteration of the rights-abuse allegations that indigenous peoples' organisations have raised. The review draws attention to the fact that safeguards are subjected to long-standing discriminatory and exclusionary decision-making practices, that FPIC requirements are mostly neglected or merely used for communication purposes, and that REDD+ is not helpful in Indigenous Peoples' struggles to defend their rights. The review concludes that 'it is unclear how Indigenous Peoples will benefit from REDD+', and that 'REDD+ risks exacerbating issues of unsecured rights and pre-existing conflicts over land' (Barletti \& Larson, 2017). ${ }^{24}$

\section{Vietnamisation: National growth and ethnic assimilation}

We have shown earlier how Vietnamese land-tenure policies translate into interventions that deliberately block security-oriented forest-farmer livelihood strategies. A range of programmes has enforced the integration of ethnic minority people into sedentary paddy rice production as a means of assimilation; paddy is at the same time a powerful marker of Kinh Vietnamese identity. As a result, many families lament that they cannot provide food for their children all year round, and when crops fail due to rice pests and flooding issues, families reportedly lose up to $50-70 \%$ of their crop. A diversified livelihood drawing on NTFPs is now out of the question because forests are either heavily degraded, formally restricted, or converted into plantation forestry. Moreover, minority families complain that small land plots and poverty restrict their ability to choose, since any deviation from standard cropping patterns might lead to disaster. ${ }^{25}$ Even for

\footnotetext{
${ }^{23}$ Meeting in Weilburg, organised by the German government and the World Bank FCPF in November 2018 and titled 'Status and Achievements of 10 years' REDD+ Preparation and Implementation'.

${ }^{24}$ Studies of the REDD process in Vietnam do not differ substantially from these general conclusions, but also reflect that both REDD and fieldwork experiences are limited (McElwee, 2017; Vurtebach \& Casse, 2017).

${ }^{25}$ Local-level poverty statistics in Lao Cai were found to be inconsistent: see Table 4 for the national level.
} 
capable households there are few means of improvement. Local opportunities for investment are few because there are already many small shops, several small livestock projects have failed, and the $6 \%$ state loans are perceived as risky.

The side effects of climate interventions in the highlands are hardly coincidental. Rather, on a national scale they are calculated by the authoritarian state as it co-opts and aligns foreign aid to a long-term, heavy-handed policy of ordering of its subjects (Duncan, 2008; Scott, 2009). When minorities are represented as primitive and backward, it implies that they need the civilising imprint of Vietnamese intervention. A wealth of international reports and academic studies have documented the resulting poverty and inequality (Baulch et al., 2009; Dang, 2010; World Bank, 2012b; Thai Nguyen University, 2014; Economist, 2015), which are equally clearly reflected in Vietnamese statistics (see Table 4). The latest Vietnam Living Standards Survey (2014) did not calculate poverty among ethnic minorities, but merely stated that more than half of ethnic minority children lived in poverty, which is 3.7 times higher than for the Kinh/Hoa group (VSO, 2015, p. 22).

Table 4. Poverty and extreme poverty levels in Vietnam (in percentages)

\begin{tabular}{|l|l|l|l|l|}
\hline & $\begin{array}{l}\text { Ethnic minority } \\
\text { poverty /extreme } \\
\text { poverty }\end{array}$ & $\begin{array}{l}\text { Majority } \\
\text { (Kinh/Hoa) } \\
\text { poverty / extreme } \\
\text { poverty }\end{array}$ & $\begin{array}{l}\text { Overall poverty / } \\
\text { extreme poverty }\end{array}$ & $\begin{array}{l}\text { Minority people's } \\
\text { share of all poor / } \\
\text { extremely poor }\end{array}$ \\
\hline $\mathbf{1 9 9 2}$ & $86.4 / 52.0$ & $53.9 / 20.8$ & $58.1 / 24.9$ & $18 / 25$ \\
\hline $\mathbf{2 0 0 6}$ & $52.3 / 29.2$ & $10.3 / 3.2$ & $16.0 / 6.7$ & $46 / 60$ \\
\hline $\mathbf{2 0 1 0}$ & $66.2^{*} / 37.4^{*}$ & $12.9^{*} / 2.9^{*}$ & $20.7^{*} / 8^{*}$ & $47\left(66^{*}\right) / 70^{*}$ \\
\hline
\end{tabular}

* Poverty measured by the new GSO-WB poverty line (World Bank, 2012b, pp. 2, 5).

Sources: Dang, 2010; World Bank, 2012b. Data are based on calculations from World Bank Living Standards Surveys $(2000,2001)$ and Vietnam Household Living Standards Surveys $(1992,2006)$.

\section{Conclusion}

This article opted to position REDD+ in Lao Cai in a perspective of conventional aid interventions, and argues that the commonplace challenges reflected in the literature also necessarily apply to 
climate-change projects. Other perspectives could have been chosen, such as general debates on REDD, but we wished to emphasise the impact of embeddedness: that the actual context tends to overrule the intent of the project. However well-intended REDD and climate projects may be, they are unable to alter crucial conditions of social organisation and governance, or to counter the self-preservation impulse of the authoritarian state.

When viewed from the highlands, there should be little doubt that the ethnic minorities are now subjected to a full-scale Vietnamisation, as predicted by anthropologist Gerald Hickey in the 1970s (Hickey, 1982, p. xxiii) and since discussed by a range of anthropologists (Rambo, 1995; Jamieson et al., 1998; Salemink, 2003; Bruun, 2017). Coerced into participating in the market economy, their customary livelihoods and the highland forest environment are rapidly eroding. The authoritarian state intrinsically relies on 'big D' development, since an alternative path, such as would be induced by the 'emergent properties', or spontaneous unfolding of small ' $d$ ' developments within a complex adaptive system (Easterly, 2013, p. 32), would necessarily challenge the key role of the Party. High modernism still has a strong grip on the Vietnamese Party-state: in the perspective of James Scott, the Party's popular mandate is built on a will to radically change existing society, including work, living patterns and moral conduct, and it has employed the armoury of social engineering to carry this through. However, this utopianism fails when held by ruling elites with no commitment to democracy or civil rights, but with access to unbridled state power (Scott, 1998, p. 89).

When such development is facilitated by the state-centred and depoliticising way of framing interventions that characterise the global climate discourse, international society is morally implicated. In 2017, the World Bank approved another budget line for Vietnam, and the REDD+ programme continues unabated. Yet the findings of the present research can hardly be a surprise to donor organisations, given that a wealth of World Bank and affiliated reports over the last 20 years have provided ample evidence of ethnic minority people's economic marginalisation, general poverty, food security issues, lack of compensation for evictions and loss of land, and general disempowerment in Vietnam.

As for REDD itself, at the local level it translates into investments for economic benefits, and not as something that places a burden on society, restricts other than minority behaviour, or changes other than minority values. Given the intentions of REDD, this may be permissible if benefits were accrued by the 'forest-dwelling communities', but under the current order this is not the case. Instead, REDD programmes are subject to selection and appropriation by provincial 
authorities to the extent that they are virtually inseparable from conventional Vietnamese state programmes for highland transformation. Authorities in charge of REDD programmes continue to perceive ethnic minority cultures as mainly technical obstacles to economic growth. Despite these cultures having sustainably practised swidden and highland agriculture and supported a tremendous biodiversity up to the modern era, they are now accused of destroying the forest. Beyond government rhetoric, the highlands are the visible frontier of Kinh Vietnamese expansion, where the authoritarian-cum-market state rolls along like an unstoppable machine.

While many observers, Vietnamese and foreign alike, believe some form of external agency is needed to assist forest-dwelling communities in their encounter with a modern market economy, the current economic growth priorities go beyond acceptable trade-offs. Both the basic safeguard instruments (a rights-based approach, the FPIC process, and broad range of stakeholder engagements) and the global VGGT standards are in practice ignored by the authoritarian state. This is in fact commonly available knowledge, and it would seem that international donors operating under the mandate of global climate deals have become insensitive to rights.

First submitted August 2018

Final draft accepted February 2019

\section{References}

ADB (Asian Development Bank) (2002). Indigenous Peoples/Ethnic Minorities and Poverty Reduction, Viet Nam. Manila: ADB.

Arnstein, S. (1969). A ladder of citizen participation. Journal of the American Institute of Planners, 35(4), 216-224.

Barletti, J. P. S., \& Larson, A. M. (2017). Rights abuse allegations in the context of REDD+ readiness and implementation. CIFOR: Info-brief, No. 190, October.

Barr, C. M., \& Sayer, J. A. (2012). The political economy of reforestation and forest restoration in Asia-Pacific: Critical issues for REDD+. Biological Conservation,

154, 9-19. doi.org/10.1016/j.biocon.2012.03.020

Baulch, B. et al. (2009). Ethnic minority poverty in Vietnam. World Bank, Discussion Draft 64272. http://documents.worldbank.org/curated/en/495591468321292112/pdf/642720WPOP10760036 1533BOPUBLICO-doc.pdf

Bernstein, H. (2006). Once were / still are peasants? Farming in a globalizing 'South'. New Political Ecology, 11(3), 399-406. DOI: 10.1080/13563460600841033

Bonnin, C., \& Turner, S. (2012). At what price rice? Food security, livelihood vulnerability, and 
state interventions in upland northern Vietnam. Geoforum, 43(1), 95-105. DOI:

10.1016/j.geoforum.2011.07.006

Booth, D. (1995). Rethinking social development: Theory, research and practice. Harlow: Longman Scientific \& Technical.

Boserup, E. (1965). The conditions of agricultural growth: The economics of agrarian change under population pressure. Chicago, IL: Aldine.

Brunner, J. (2012). Biodiversity conservation in Vietnam: A perfect storm. IUCN:

https://cmsdata.iucn.org/downloads/iucn_nbsap_workshop_march_2012_paper_final.pdf

Bruun, O. (2012). Sending the right bill to the right people: Climate change, environmental degradation, and social vulnerabilities in Central Vietnam. Weather, Climate, and Society, 4(4), 250-262. DOI: 10.1175/WCAS-D-11-00040.1

Bruun, O., \& Casse, T. (2013). Climate change, adaptation and the environment in central Vietnam. In O. Bruun \& T. Casse (Eds.), On the frontiers of climate and environmental change: Vulnerabilities and adaptations in central Vietnam, pp. 1-22. Heidelberg: Springer.

Bruun, O., \& Olwig, M. F. (2015). Is local community the answer? The role of 'local knowledge' and 'community' for disaster prevention and climate adaptation in Central Vietnam'. Asian Journal of Social Science, 43(6), 811-836. DOI: 10.1163/15685314-04306008

Bruun, O. (2017). 'Tragedy in the Highlands: Vietnamese government policy and UN-REDD complicity in forest destruction and ethnic minority displacement'. Unpublished paper.

Bruun, O., \& Luu, B. N. (2018). Local and indigenous knowledge for disaster prevention and livelihood protection in rural North-Central Vietnam. Journal of Vietnamese Studies, 13(2), 74101. DOI: $10.1525 / v s .2018 .13 .2 .74$

Chambers, R. (2005). Ideas for development. New York: Earthscan/Routledge.

Chayanov, A. V. et al. (1966). A. V. Chayanov on the theory of peasant economy. Homewood, IL: The American Economic Association.

Clement, F., \& Amezaga, J. M. (2009). Afforestation and forestry land allocation in northern Vietnam: Analysing the gap between policy intentions and outcomes. Land Use Policy, 26(2), 458-470. DOI: 10.1016/j.landusepol.2008.06.003

Corbera, E., Hunsberger, C., \& Vaddhanaphuti, C. (2017). Climate change policies, land grabbing and conflict: perspectives from Southeast Asia. Canadian Journal of Development Studies / Revue canadienne d'études du développement, 38(3), 297-304. DOI: 10.1080/02255189.2017.1343413

Crewe, E., \& Harrison, E. (1998). Whose development? An ethnography of aid. London: Zed Books.

Dalton, G. (1967). Tribal and peasant economies: Readings in economic anthropology. New York: Doubleday. 
Dang, Hai-Anh (2010). 'A widening poverty gap for ethnic minorities'. Indigenous people, poverty and development'. Chapter 8. World Bank. Accessed 3 March 2017 at http://siteresources.worldbank.org/EXTINDPEOPLE/Resources/4078011271860301656/Chapter_8_Vietnam.pdf

Diamond, L., \& Plattner, M. F. (2016). Introduction. In L. Diamond et al. (Eds.), Authoritarianism goes global: The challenge to democracy. Baltimore, MD: Johns Hopkins University Press.

Duncan, C. R. (2008). Introduction. In C.R. Duncan (Ed.), Civilizing the margins: Southeast Asian government policies for the development of minorities. Ithaca, NY: Cornell University Press.

Easterly, W. (2013). The tyranny of experts: Economists, dictators, and the forgotten rights of the poor. New York: Basic Books.

The Economist (2015, 4 April). Out of sight: Ethnic minorities in Vietnam. 4 April.

The Economist (2018, 31 January). Daily Chart: Democracy continues its disturbing retreat. 31 January.

Ferguson, J. (1990). The anti-politics machine: 'Development', depoliticisation, and bureaucratic power in Lesotho. Cambridge: Cambridge University Press.

Friedman, J. (1994). Cultural identity and global process. London: Sage Publications.

Fortier, F. (2013). Viet Nam's food security: A castle of cards in the winds of climate change. In O. Bruun \& T. Casse (Eds.), On the frontiers of climate and environmental change: Vulnerabilities and adaptations in central Vietnam, pp. 241-256. Heidelberg: Springer.

Fox, J., Dao Minh Truong, Rambo, A. T., Nghiem Phuong Tuyen, Le Trong Cuc, \& Leisz, S. (2000). Shifting cultivation: A new old paradigm for managing tropical forests. BioScience, 50(6), 1, 521528.

Fox, J., Castella, J., \& Siegler, A. D. (2014). Swidden, rubber and carbon: Can REDD+ work for people and the environment in Montane Mainland Southeast Asia? Global Environmental Change, 29, 318-326. doi.org/10.1016/j.gloenvcha.2013.05.011

Freedom House. (2017). 'Freedom in the World 2017. Populists and Autocrats: The Dual Threat to Global Democracy'. Accessed 20 January 2018 at https://freedomhouse.org/report/freedomworld/freedom-world-2017

Hoeffler, A., \& Outram, V. (2011). Need, merit or self-interest - what determines the allocation of aid? Review of Development Economics, 15(2), 237-250. doi.org/10.1111/j.14679361.2011.00605.x

Gainsborough, M. (2010). Present but not powerful: Neoliberalism, the state, and development in Vietnam. Globalizations, 7(4), 475-488. DOI: 10.1080/14747731003798435

Gardner, K., \& Lewis, D. (2015). Anthropology and development: Challenges for the twenty-first century. London: Pluto Press. 
Geertz, C. (1963). Agricultural involution: The processes of change in Indonesia. Berkeley, CA: University of California Press.

Grillo, R. D., \& Stirrat, R. L. (1997). Discourses of development: Anthropological perspectives. London: Bloomsbury Publishing.

Hickey, G. (1982). Free in the forest: Ethnohistory of the Vietnamese Central Highlands, 1954-76. New Haven, CT: Yale University Press.

Hoang Cam (2011). 'Forest thieves': State resource policies, market forces, struggles over livelihood and meanings of nature in a Northwestern valley of Vietnam. In Sikor, T. et al., (Eds.), Upland transformations in Vietnam, pp. 92-114. Singapore: NUE Press.

IPCC. (2014). Summary for policymakers. In: Climate Change 2014: Impacts, Adaptation, and Vulnerability. Part A: Global and Sectoral Aspects. Contribution of Working Group II to the Fifth Assessment Report of the Intergovernmental Panel on Climate Change [Field, C.B., V.R. Barros, D.J. Dokken, K.J. Mach, M.D. Mastrandrea, T.E. Bilir, M. Chatterjee, K.L. Ebi, Y.O. Estrada, R.C. Genova, B. Girma, E.S. Kissel, A.N. Levy, S. MacCracken, P.R. Mastrandrea, and L.L. White (eds.)]. Cambridge and New York: Cambridge University Press, pp. 1-32.

IPCC. (2007). Climate Change 2007: Working Group II: Impacts, Adaptation and Vulnerability. http://www.ipcc.ch/publications_and_data/ar4/wg2/en/ch4s4-7-2.html

Jamieson, N. (1991). Culture and development in Vietnam. Honolulu, HI: East-West Center.

Jodoin, S. (2017). Forest preservation in a changing climate: REDD+ and Indigenous and Community Rights in Indonesia and Tanzania. Cambridge: Cambridge University Press.

Kemf, E., \& Quy, Vo (1999). Ethnic minorities and protected areas in Vietnam: The effect of land use on biodiversity in the buffer and core zones of Yok Don National Park, Vietnam. In IWGIA, Indigenous Peoples and Protected Areas in South and Southeast Asia. Copenhagen: IWGIA.

Long, N. (1977). An Introduction to the sociology of developing societies. London: Tavistock.

Long, N. (2001). Development sociology: Actor perspectives. Abingdon: Routledge.

Long, N., \& Long, A. (Eds.). (1992). Battlefields of knowledge: The interlocking of theory and practice in social research and development. London and New York: Routledge.

Marino, E., \& Ribot, J. (2012). Special Issue Introduction: Adding insult to injury: Climate change and the inequities of climate intervention. Journal of Environmental Change, 22(2), 323-328. DOI: 10.1016/j.gloenvcha.2012.03.001

McElwee, P. (2016). Forests are gold: Trees, People, and environmental rule in Vietnam. Washington, WA: University of Washington Press.

McElwee, P. (2017). Doing REDD+ work in Vietnam: Will the new carbon focus bring equity to forest management. In S. Fiske \& S. Paladino (Eds.), The Carbon Fix: Global Equity and the New Environmental Regime. Walnut Creek, CA: Left Coast Press.

Mosse, D. (Ed.). (2011). Introduction: The anthropology of expertise and professionals in 
international development. In Adventures in Aidland: The Anthropology of expertise and professionals in international development, pp. 1-31. New York: Berghahn.

Nhinh Do Thi \& Bruun, O. (2012). Interacting Cultural and Environmental Change: The Co (Cua) Minority of Central Vietnam. In O. Bruun \& T. Casse (Eds.), On the frontiers of climate and environmental change: Vulnerabilities and adaptations in central Vietnam, pp. 218-240. Heidelberg: Springer.

Ortmann, S. (2017). Environmental governance in Vietnam: Institutional reforms and failures. Berlin: Springer Verlag.

Rambo, T. (1995). Defining highland development challenges in Vietnam: Some themes emerging from the conference. In T. Rambo et al. (Eds.), The challenges of highland development in Vietnam. Honolulu, HI: East-West Center, Program on Environment.

Rambo, T. et al. (Eds.) (1995). The challenges of highland development in Vietnam. Honolulu, $\mathrm{HI}$ : East-West Center, Program on Environment.

REDD-MONITOR (2016). The World Bank's Forest Carbon Partnership Facility 'has not saved a single hectare of forest'. http://www.redd-monitor.org/2016/11/17/the-world-banks-forestcarbon-partnership-facility-has-not-saved-a-single-hectare-of-forest/

Rist, G. (1997). The history of development: From Western origins to global faith. London: Zed Books.

Rutzen, D. (2016). Civil Society under assault. In L. Diamond et al. (Eds.), Authoritarianism goes global: The challenge to democracy. Baltimore, MD: Johns Hopkins University Press.

Salemink, O. (2003). The ethnography of Vietnam's Central Highlands. Honolulu: University of Hawaii Press.

Salemink, O. (2011). A view from the mountains: A critical history of lowlander-highlander relations in Vietnam. In T. Sikor et al. (Eds.), Upland transformations in Vietnam. Singapore: NUE Press.

de Sardan, J. P. O. (1988). Peasant logics and development project logics. Sociologia Ruralis, 28, $2 / 3$.

de Sardan, J. P. O. (2005). Anthropology and development: Understanding contemporary social change. London: Zed Books.

Schulz, K., \& Siriwardane, R. (2015). Depoliticised and technocratic? Normativity and the politics of transformative adaptation. Lund: Earth System Governance Working Paper, No. 33.

Scott, J. C. (1976). The moral economy of the peasant: Rebellion and subsistence in Southeast Asia. New Haven, CT: Yale University Press.

Scott, J. C. (1998). Seeing like a state: How certain schemes to improve the human condition have failed. New Haven, CT: Yale University Press. 
Scott, J. C. (2009). The art of not being governed: An anarchist history of upland Southeast Asia. New Haven, CT: Yale University Press.

Sen, A. (1999). Development as freedom. New York: Oxford University Press.

Sikor, T. (2011). Introduction: Opening boundaries. In T. Sikor et. al. (Eds.), Upland transformations in Vietnam, pp. 1-24. Singapore: NUE Press.

Thai Nguyen University (2014). International conference: Sustainable development and ethnic minority poverty reduction in mountainous regions. Thai Nguyen: World Bank and Thai Nguyen University Publishing House.

Turner, S., \& Michaud, J. (2008). Imaginative and Adaptive Economic Strategies for Hmong Livelihoods in Làào Cai Province, Northern Vietnam. Journal of Vietnamese Studies, 3(3), 158190. DOI: 10.1525/vs.2008.3.3.158

UNFCCC (Framework Convention on Climate Change) (2011). FCCC/CP/2010/7/ Add.1. Accessed 12 December 2017 at http://unfccc.int/resource/docs/2010/cop16/eng/07a01.pdf

UNFPII (United Nations Permanent Forum on Indigenous Issues) (2011). 'Indigenous Peoples and the UN-REDD Programme: An overview'. Secretariat of the UNFPII.

UN-REDD (2012). 'Lessons Learned. Viet Nam UN-REDD Programme, Phase 1'.

http://www.vietnam-

redd.org/Upload/Download/File/Lessons Learned UN REDD VN phase 1 final 3103.pdf

UN-REDD (2016a). 'Forest Land Allocation in Viet Nam: Policies, Processes and Practices'. UNREDD Phase 2 Programme.

UN-REDD (2016b). 'Institutional Capacity to Implement Assess the Relevant Policies, Laws and Regulations (PLRs) with respect to REDD + Safeguards'. Sub-Technical Working Group on Safeguards. Report presented 24 August in Hanoi.

UN-REDD (2012). Vietnam, assessments of phase $1 \ldots$

USAID (2013). 'Vietnam tropical forest and biodiversity assessment'. US Foreign Assistance Act, Section 118/119 Report, August.

Vien Tran Duc (2012). Forestland management policies in Vietnam. https://www.researchgate.net/publication/237746324_FORESTLAND_MANAGEMENT_POLICIES_ IN_VIETNAM_AN_OVERVIEW

VSO (V ietnam Statistical Office) (2015). V ietnam Household Living Standards Survey 2014. Accessed 15 February 2018 at www.gso.gov.vn/Default_en.aspx?tabid=491

Vurtebach, Z., \& Casse, T. (2017). Multi-level challenges to REDD+ implementation in Vietnam. Unpublished paper.

World Bank. (2009). Country Social Analysis: Ethnicity and Development in Vietnam. Social Development Unit, East Asia and Pacific Region. Washington, DC: World Bank. 
World Bank. (2012a). Guidelines on Stakeholder Engagement in REDD+ Readiness With a Focus on the Participation of Indigenous Peoples and Other Forest Dependent Communities. April 20 (revision of 25 March version).

World Bank. (2012b). 2012 Vietnam Poverty Assessment: Well Begun, Not Yet Done: Vietnam's Remarkable Progress on Poverty Reduction and the Emerging Challenges. Hanoi: World Bank. https://www.forestcarbonpartnership.org/sites/forestcarbonpartnership.org/files/Documents/P DF/July2012/Guidelines/on/Stakeholder/Engagement/April/20/2012.pdf

Zink, E. (2013). Hot science, high water. Assembling nature, society and environmental policy in contemporary Vietnam. Copenhagen: NIAS Press. 